\title{
The lateral facies of ignimbrites at Laacher See volcano
}

\author{
Rolf Schumacher ${ }^{1,2}$ and Hans-Ulrich Schmincke ${ }^{1}$ \\ ${ }^{1}$ Institut für Mineralogie, Ruhr-Universität, D-4630 Bochum, Federal Republic of Germany \\ ${ }^{2}$ Institut für Mineralogie, Albert-Ludwigs-Universität, D-7800 Freiburg, Federal Republic of Germany
}

\begin{abstract}
Valley-fill ignimbrites of the Middle Laacher See Tephra (MLST) in the proximal depositional fan south of Laacher See volcano are laterally continuous with fine-grained overbank-facies deposits, $0.5-1.5 \mathrm{~m}$ thick, covering higher elevations and interfluves between the paleovalleys. The overbank deposits consist of up to 12 ash layers, each $4-10 \mathrm{~cm}$ thick, which show internal structures typical of ash-flow transport, such as poor sorting, reverse size-grading of pumice, local normal grading of coarse ash-sized lithics above a fine-grained basal layer, cross-stratification behind obstacles, and erosional unconformities. Thickness, median grain-size, and number of individual layers decrease systematically with distance from the vent. Overbank ash layers thicken at the valley slopes and form discrete valley-fill ignimbrite flow units in the paleochannels with median grain size increasing from $\leq 63 \mu \mathrm{m}$ to $\leq 350 \mu \mathrm{m}$. Toward the center of paleochannels, however, the well-defined overbank facies is obscured by mutual erosion of individual flow units. Overlapping data fields in ternary grain-size variation diagrams indicate the overbank facies to have evolved from ash flows chiefly through depletion of lapilli and coarse ash. Overbank-facies ash layers do not represent dust layers resulting from elutriation clouds of ash flows (co-ignimbrite ash) or surge deposits developed on higher ground due to low concentration of solids. They are similar in some parameters to Taupo-type ignimbrite veneer deposits, but are interpreted differently. The thin, fine-grained, Laacher See ash layers are thought to have been deposited from diluted portions of the flow proceeding directly from the eruption column while the main pyro-
\end{abstract}

Offprint requests to: $\mathrm{R}$ Schumacher clastic flows were confined to the paleovalleys radiating away from the eruptive center. The wide distribution of the thin ash layers is attributed to the balance of deposition from various flow parts and turbulent entraining and heating of ambient air that sustained sufficient mobility of the diluted flows to spread across hills and level ground.

\section{Introduction}

Fine-grained ash layers interbedded with fall deposits have been recognized in Plinian-type tephra sequences for many decades. At Laacher See volcano and elsewhere they were traditionally interpreted as slowly settled fallout dust following more rapid sedimentation of the underlying pumice beds with which they were believed to be cogenetic (e.g., Frechen 1953, 1976). More recently, some of the thin but widespread ash layers at Laacher See were interpreted to have been deposited from ground-hugging ash clouds accompanying valley-fill ash flows (Schmincke 1970, 1977). This interpretation was based chiefly on the poor sorting, fine grain size, massive structure, and especially lateral gradation into valley-fill ignimbrites. Similar relationships of fine-grained ash layers were noted on Fogo volcano (Azores) by Walker and Croasdale (1971).

Within the past 15 years, fine-grained ash layers interbedded with fall deposits have received increased attention and a number of interpretations were suggested. Few, however, have been described in sufficient detail to allow a clear distinction of different depositional processes.

We have studied the regional distribution, grain size, and lithology of thin, fine-grained ash layers laterally passing into valley-fill ignimbrites 
in the well-exposed proximal facies of the Laacher See tephra blanket. We have tested several models for their origin: (a) ash elutriated from valley flows and deposited as dust layers on higher ground, (b) surges, laterally continuous with pyroclastic flows and developed due to low solids concentration, (c) trail deposits left after passage of a pyroclastic flow, and (d) lateral overbank deposit.

\section{Regional setting}

Laacher See volcano located in the East Eifel volcanic field (Fig. 1a) erupted at least $5 \mathrm{~km}^{3}$ (DRE) of phonolitic magma 11000 years ago (Bogaard and Schmincke 1984, 1985). Its entire tephra sequence, which is $>50 \mathrm{~m}$ thick near the vent, is subdivided into the Lower (LLST), Middle (MLST-A, B, and C), and Upper (ULST) Laacher
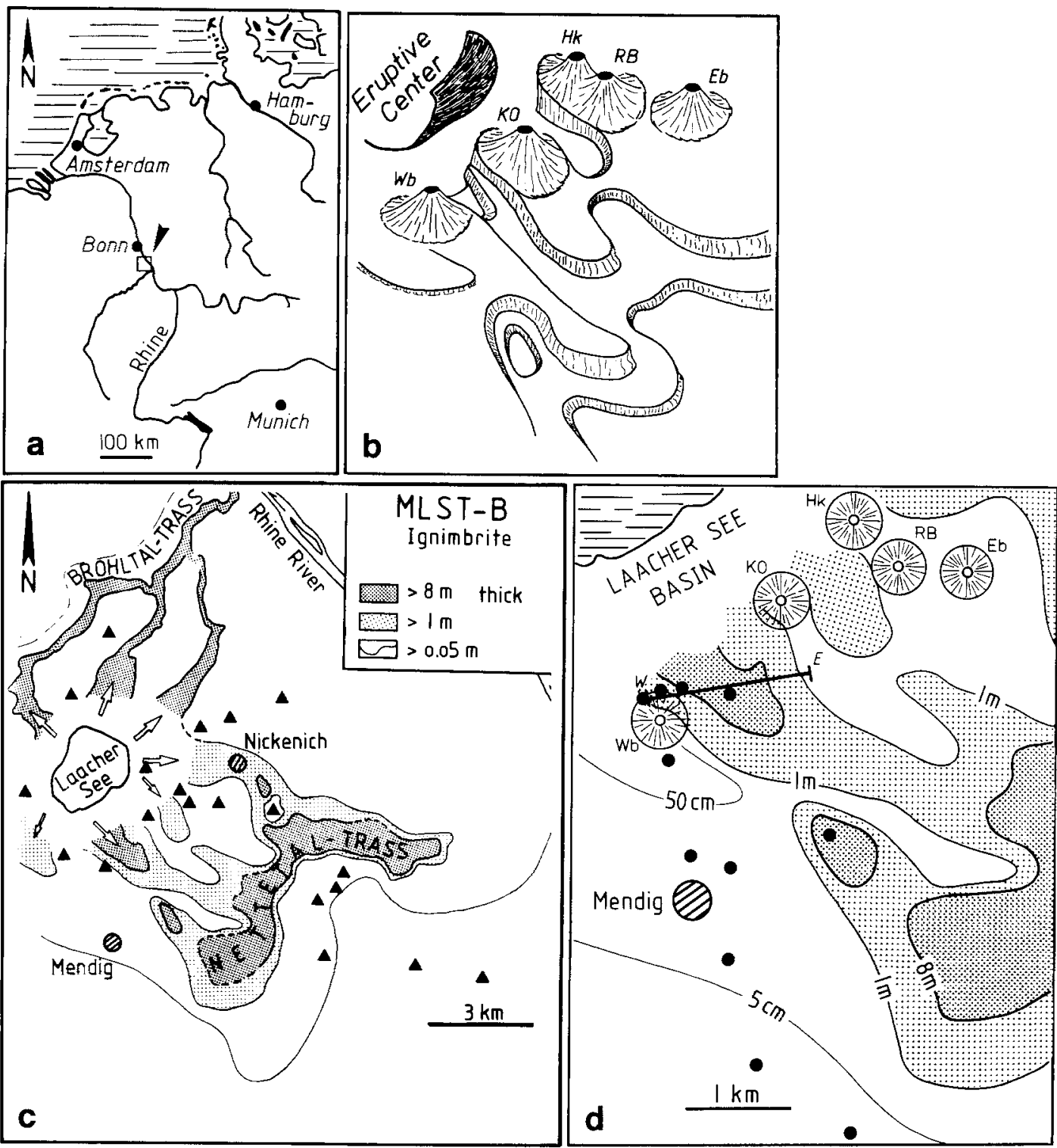

Fig. 1. a Map showing the location of the Laacher See study area about $40 \mathrm{~km}$ south-southeast of Bonn. b Schematic illustration of topography south of Laacher See volcano dominated by valleys between scoria cones. $W b$, Wingertsberg; $K O$, Krufter Ofen; $H k$, Heidekopf; $R B$, Roter Berg; $E b$, Eppelsberg. c, d Regional thickness distribution of the MLST-B ignimbrite around Laacher See (Bogaard and Schmincke 1984), filled triangles are older basanitic/tephritic scoria cones); WE profile in $\mathbf{d}$ indicates section across the Mendig paleovalley shown in Fig. 3 


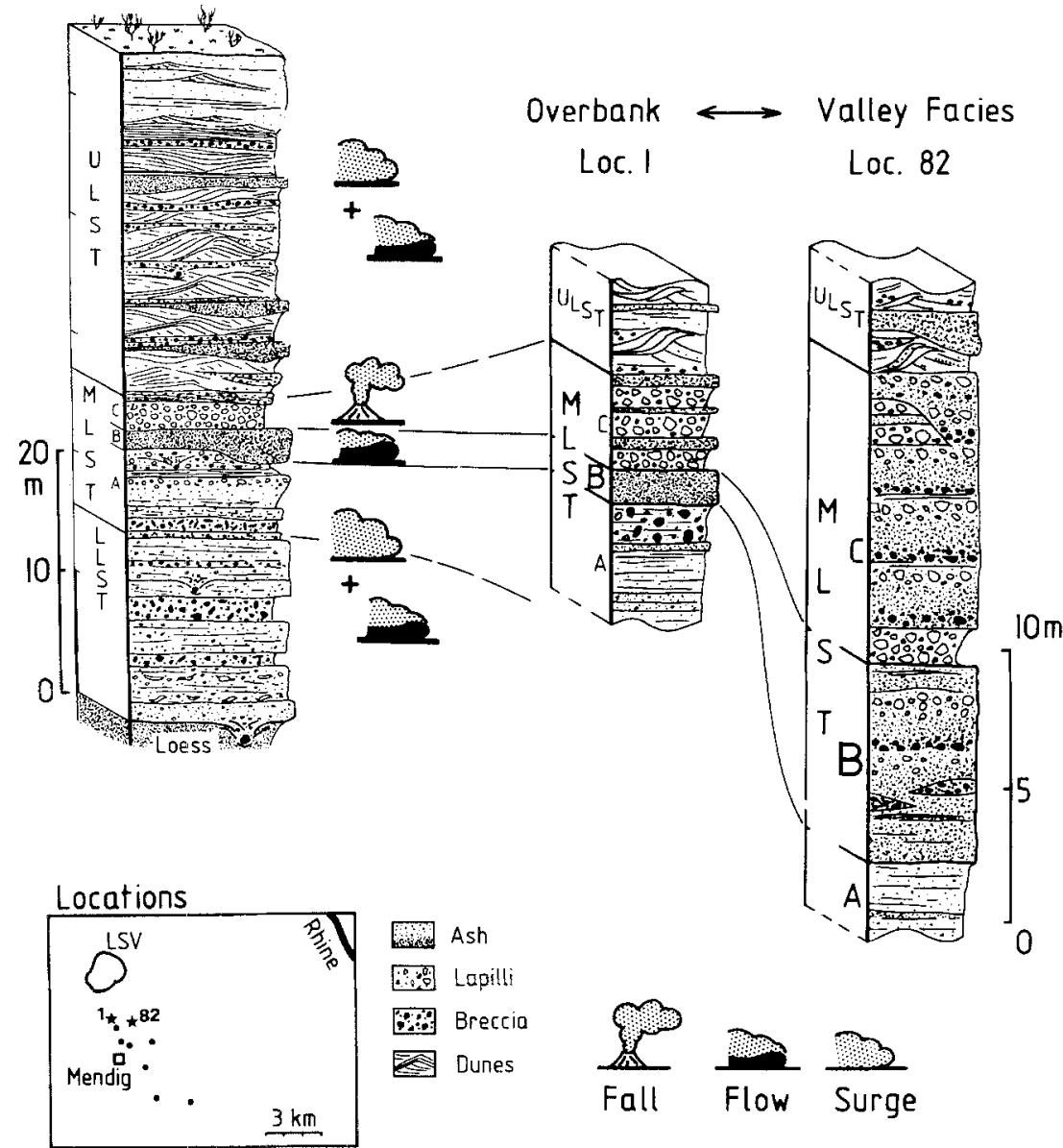

Fig. 2. Stratigraphy of proximal Laacher See Tephra (LST) shown as total section with inserts illustrating contrasts between overbank and valley facies. Generally, valley facies is dominated by ignimbrites of MLST-B and -C stratigraphic intervals, a few tens of $\mathrm{m}$ thick. The index map shows sample locations and location of vertical sections south of Laacher See volcano $(L S V)$. MLST-B is $0.5 \mathrm{~m}$ thick at locality 1 (overbank)
See Tephra (Fig. 2), which differ in lithology, magma composition, and eruptive mechanisms. The complex eruptive history of Laacher See volcano including initial phreatic, major Plinian-type convecting (LLST), alternating Plinian-type convecting and collapsing (MLST), and major phreatomagmatic (ULST) stages is recorded in various depositional fans of the proximal tephra series around the eruptive center (Schmincke et al. 1989).

The MLST-B submember, corresponding to the T1 pyroclastic-flow phase defined by Freundt and Schmincke (1986) north of Laacher See, is characterized by abundant and alternating fall and flow deposits south and east of the volcano. Plinian-type fall deposits alternating with minor ash-flow deposits formed widespread fans extending predominantly to the east-northeast. A very fine grained ash layer, a few $\mathrm{cm}$ thick, is intercalated within the ash-flow deposits. Its areal distribution parallel to the fallout fan and grain size characteristics indicate that this ash was deposited as dust layer from co-ignimbrite ash clouds during a pause in ignimbrite deposition
(Schumacher and Schmincke 1987; Schumacher 1988).

Pyroclastic flows preferentially descended through passes between older scoria cones of the rim surrounding Laacher See basin and accumulated in paleovalleys (Fig. 1b-d). Valley-fill ignimbrites up to $10 \mathrm{~m}$ thick are laterally continuous with thin, 5- to 150-cm-thick, compound ash layers covering higher grounds and interfluves chiefly in the Mendig Fan, the largest of five pyroclastic flow fans. Isopach maps of Fig. $1 \mathrm{c}-\mathrm{d}$ show the areal distribution of the MLST-B ignimbrite, wich is described in more detail below.

\section{Field characteristics}

We distinguish overbank and valley facies in the MLST-B ignimbrite in sections transverse to the direction of transport (Figs. 3, 4). The overbank facies up to $1.5 \mathrm{~m}$ thick (Fig. 4) is represented by a widespread ash blanket contrasting with the valley facies that consists of channelized flows with a cumulative thickness of $6-10 \mathrm{~m}$. Both facies grade 

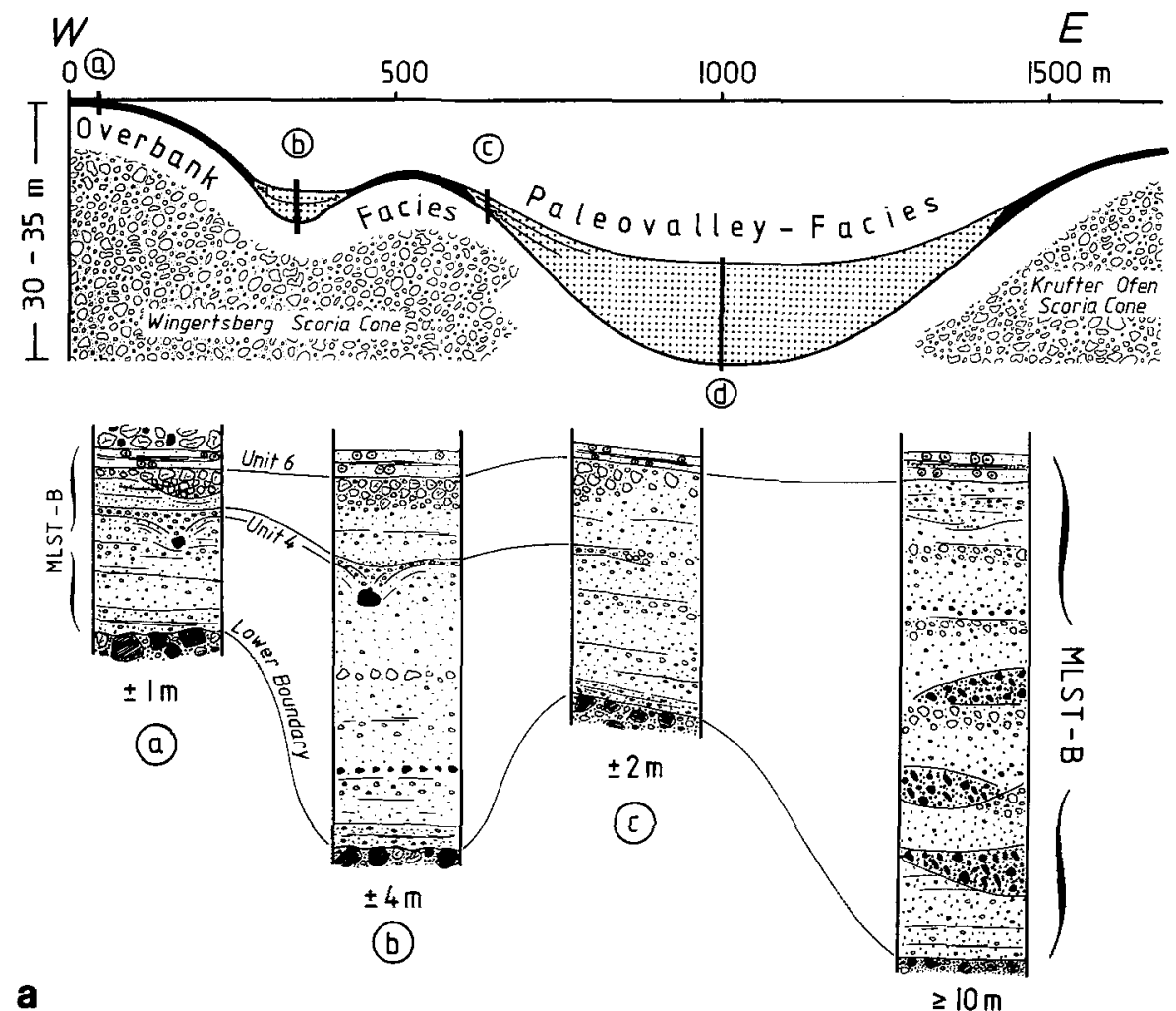

a

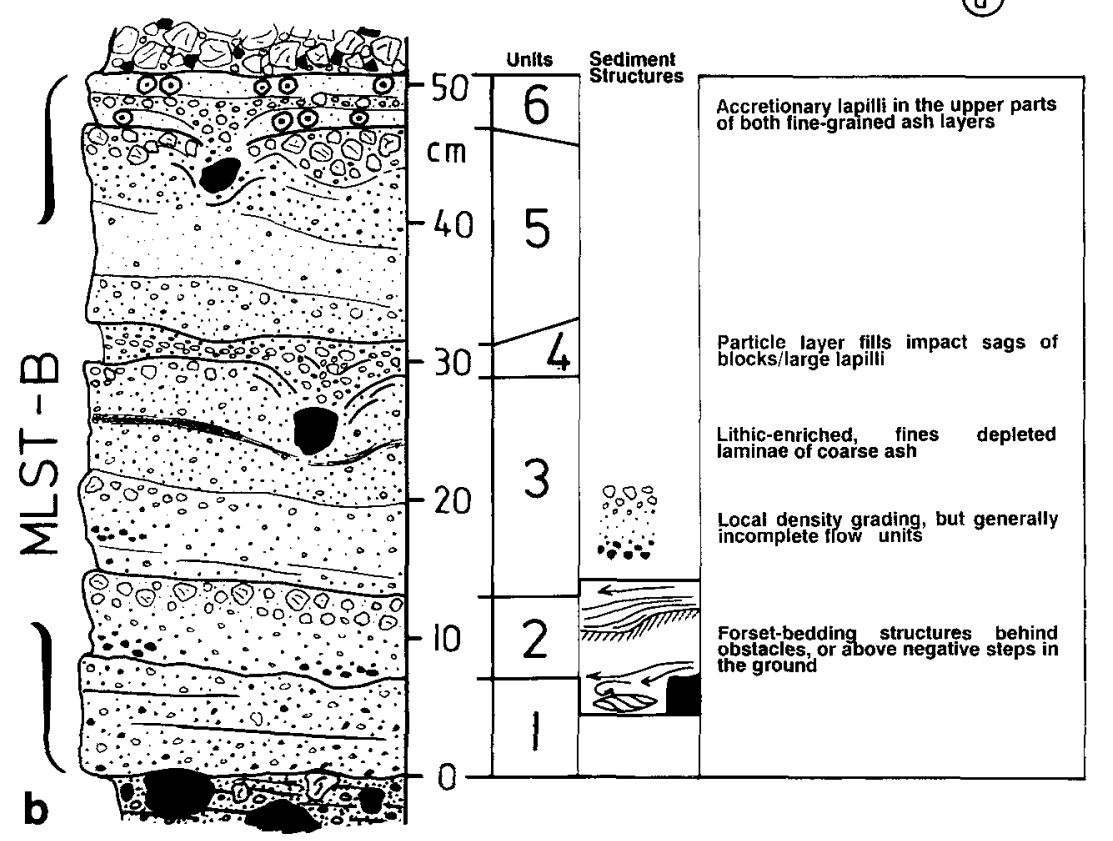

Fig. 3. a Schematic EW-section across the Mendig paleovalley showing field relations of overbank facies draping the Wingertsberg and Krufter Ofen scoria cones and the paleovalley-fill in between. Vertical sections illustrate depositional characteristics: thin, bedded ash layers $(a)$ swell to about $4 \mathrm{~m}$ thickness in the small channel on the north flank of Wingertsberg ( $b$; Fig. 4 ); along the paleovalley margin, unit 5 and the pumice concentration of unit 6 disappear (c), whereas top unit 7 persists throughout the valley facies. The paleovalley fill is characterized by mutual erosion of flow units indicated by remaining lenses of lithic-rich basal zones (d). b Detailed vertical section $a$, illustrating stratigraphic subdivision of overbank facies into each other throughout a 25-50-m-wide transition zone along the paleovalley margin (Fig. 4d). Local erosional unconformities between flow units do not allow correlation of each valley flow with a specific thin overbank ash layer. The stratigraphic subdivision was defined in the overbank facies and was then traced into the valley fill.

\section{Overbank facies}

The overbank facies is subdivided into six stratigraphic intervals, each of which comprising up to three ash layers (flow units; Fig. 3b). Subdivision into intervals is based on changes in color, grainsize distribution, and type of clasts. All but unit 4 
are poorly sorted and contain small pumice lapilli, lithic fragments of Devonian slates, and Quaternary basanitic-tephritic lava and scoria. Ballistic blocks and large lapilli are associated with well-sorted pumiceous layers such as unit 4 or one layer in unit 6 (Fig. 3b).

Generally, even ash layers $<10 \mathrm{~cm}$ thick show inversely graded pumice in their upper parts; fine-grained basal layers and normal grading of flakes of country rock occur only locally (incomplete flow units). Somewhat discontinuous, lithicenriched laminae up to $5 \mathrm{~mm}$ thick are interbedded with ash layers, especially in unit 3. The laminae lack very fine ash and consist predominantly of particles $0.5-1 \mathrm{~mm}$ in size. Furthermore, topography-related, foreset-bedding structures occur behind obstacles or negative steps in the ground suggesting local surge deposits (Figs. 3a, 4e).

Four discrete layers are important stratigraphic markers. (1) Unit 4, composed of wellrounded small pumice lapilli, can be traced from the paleovalley margin throughout the overbank facies north of Wingertsberg (Fig. 3). The layer thickens in bomb sags. (2) The inversely graded pumice concentration layer in the upper part of unit 5 . About $100 \mathrm{~m}$ away from the valley margin, the layer becomes disrupted and is represented largely by isolated lenses with internal clast-supported fabric. (3) The uppermost unit 6 comprises two very fine-grained ash layers with accretionary lapilli that are separated from each other by a fairly well-sorted pumiceous layer.

Despite small-scale erosion of flow units, all stratigraphic intervals can be traced laterally throughout the overbank facies and a narrow transitional zone into the marginal valley-fill ignimbrite. The thin-bedded ash locally rests on slopes as steep as $30^{\circ}$ (Fig. 4). In this marginal zone, erosion by subsequent flows becomes stronger. At some places, the pumice concentration layer of unit 5 directly rests on the lowermost unit 1 , as a result of erosion by the flow prior to the deposition of the pumice itself. No evidence for other erosional processes such as slumping into the valley is obvious. The uppermost ash layers of unit 6 are draped over the entire overbank and marginal facies, but thicken even in small depressions.

\section{Valley facies}

Units 1 and 2 were identified in the marginal valley-fill by their greenish and faint-reddish color. The ash layers of units 3 through 5 could not be exactly correlated to the valley-fill despite pronounced grading of lithics and pumice separating individual flow units from each other within about $150 \mathrm{~m}$ laterally into the ignimbrite. Unit 4, the excellent marker horizon of the overbank area, is eroded by subsequent pyroclastic flows. In the center of the valley, erosion of flow units becomes still stronger, and lithic-rich basal zones, some with imbrication fabric of platy slate fragments (Schmincke 1977) as well as pumiceous top zones are reduced to variably isolated lenses (Fig. 3). Unit 6 persists throughout the valley facies, mantling the deposits. Its thickness increases from $3 \mathrm{~cm}$ in the overbank to about $30 \mathrm{~cm}$ in the paleovalley facies. Both ash layers contain abundant accretionary lapilli.

\section{Variation with distance from source}

Within the overbank facies, number, thickness, and grain size of ash layers decrease with increasing distance from Laacher See, while accretionary lapilli become more abundant. Four $\mathrm{km}$ south of the vent, only four layers persist, and at $7 \mathrm{~km}$ a single layer $3 \mathrm{~cm}$ thick remains. Internal structures within $4 \mathrm{~km}$ from the vent include very low angle cross-stratification of laminae and leeside bedding of pumice behind obstacles. In the valley-fill ignimbrite, the thickness and bedding characteristics described above persist. The decreasing number of ash layers in the overbanks reflects the absence of overbank deposition from some of the valley flows emplaced farther south and is not due to erosion. In other words, north of Wingertsberg facies transition from overbank to paleovalley is more or less gradational. Farther south, the transition is more likely an abrupt change due to a hiatus between individual overbank ash layers.

\section{Grain-size characteristics}

Grain-size analyses were performed on more than 60 samples from overbank and valley facies (Fig. 1d). We sampled the entire ash layer of overbank flow units, but only the ash-flow matrix from the central parts of individual flow units of the valley fill in order to determine if deposition of small lapilli to ash-sized tephra was affected by topography. The distribution of coarse lithics and pumice was easily studied in the field. Tephra was disaggregated by $\mathrm{H}_{2} \mathrm{O}_{2}$ and wet-sieved in $1 \Phi$ intervals. The fines $<63 \mu \mathrm{m}$ were separated by an ultrasonic sieving apparatus into fractions of 30,15 , 

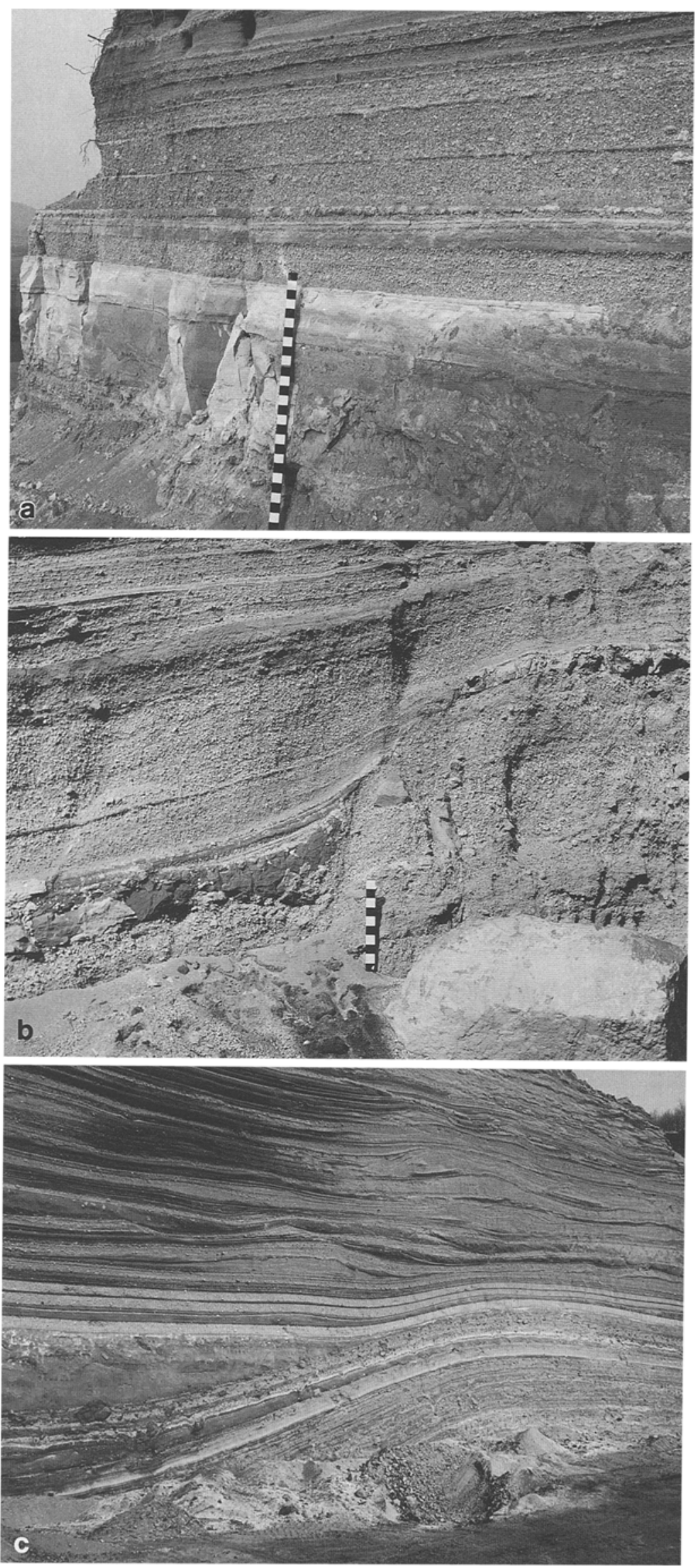

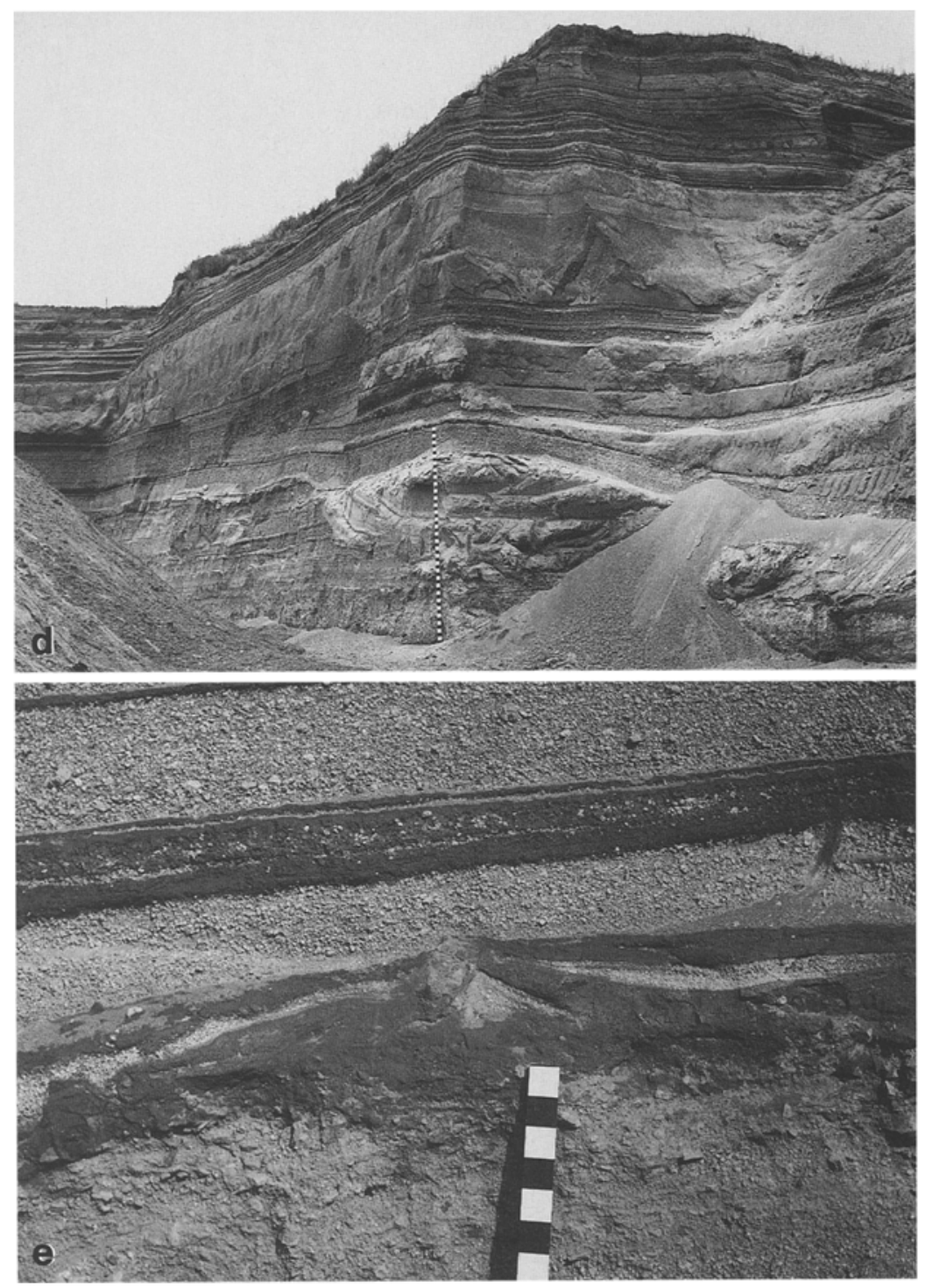

Fig. 4. a MLST-B ash-flow deposit (ca. $140 \mathrm{~cm}$ thick) in overbank facies on top of Wingertsberg about $300 \mathrm{~m}$ southeast of main paleochannel (Fig. 3a). Scale marked in 10-cm intervals. Thin ash layers above scale interbedded with fallout-lapilli layers are also pyroclastic-flow overbank deposits and thicken in paleochannels (Fig. 4e). b Thickening of MLST-B deposits in small depression formed by synvolcanic faulting during deposition of Lower Laacher See Tephra. c MLST-B (ca. $4 \mathrm{~m}$ thick) in subsidiary channel (Fig. 3a) laterally thinning markedly over topographic high (overbank). Phreatomagmatic ULST with breccia, sand wave, and massive beds in upper part of photograph. Section transverse to transport direction. d Margin of main paleochannel ca. $3 \mathrm{~km}$ southeast of Laacher See. MLST-B pyroclastic flows have eroded $2 \mathrm{~m}$ deep into channel in LLST fallout deposits. Overbank deposits to left of erosional channel are $<20 \mathrm{~cm}$ thick. Note thickening of thin overbank ash layers above scale from left toward center of paleochannel at right. Compare with overbank section in a-c. Thicker ignimbrites in upper part of photograph (lower ULST) spread across leveled paleochannel on even ground. e Lenses of well-rounded pumice lapilli formed around obstacle (lithic block). The lenses are separated by fine-grained, accretionary-lapilli-bearing ash layers at top of MLST-B. Similar lenses form at fault scarps in $\mathbf{b}$

and $5 \mu \mathrm{m}$. Median diameter (Md) and Inman sorting parameters $\left(\sigma_{\Phi}\right)$ were obtained from cumulative distribution curves.

Generally, the grain-size distribution is bimodal with modes either at $250-125 \mu \mathrm{m}$ or, in finergrained samples, at $125-63 \mu \mathrm{m}$, and the second mode at $15 \mu \mathrm{m}$, but at distal locations samples from the overbank facies tend to be unimodal with the mode between 30 and $63 \mu \mathrm{m}$. All samples are poorly sorted: Inman sorting varies between 1.75-3.8, and median grain-size (Md) ranges from $35 \mu \mathrm{m}$ in overbank samples to about $350 \mu \mathrm{m}$ in 

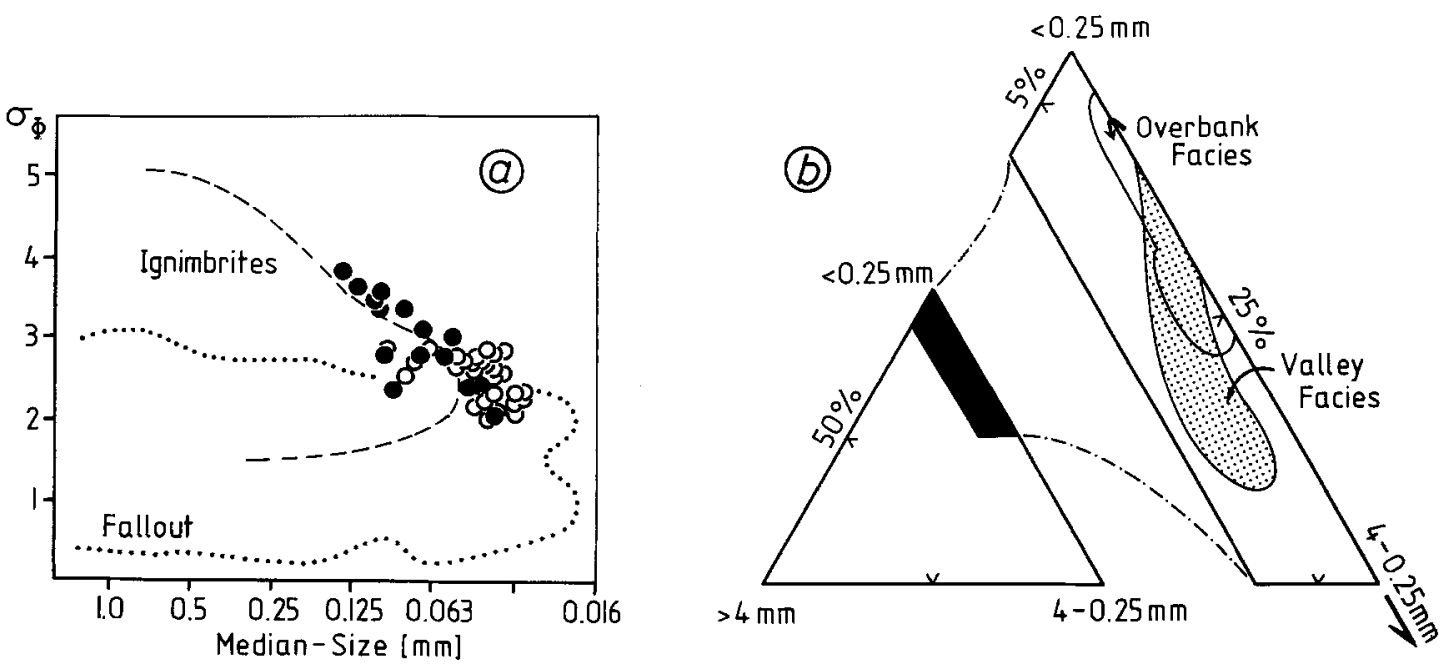

Fig. 5. a Grain-size data plotted in the $\mathrm{Md}(\mathrm{mm})$ vs sorting $\left(\sigma_{\phi}\right)$ diagram. Only a few samples directly match the variation area for ignimbrites, but the $\mathrm{Md} / \sigma_{\phi}$ data set parallels the variation area. b Ternary diagram of grain-size data. Deposits form two overlapping data sets indicating that deposits differ only in amounts of coarse fraction. Grain-size fractions $>4,4-0.25$, and $<0.25 \mathrm{~mm}$ according to Walker et al. (1981b)

the valley facies. Grain-size data were plotted in the $\mathrm{Md}_{\Phi}$ versus $\sigma_{\Phi}$ diagram (Walker 1971; Fig. 5a). Not all samples fall within the variation field for ignimbrites, but even data for overbank deposits show the $\mathrm{Md}_{\Phi} / \sigma_{\Phi}$ characteristics of ignimbrites. In a ternary diagram, grain-size data form two overlapping sets of valley and overbank fa- cies indicating the close relationship between the two deposits (Fig. 5b).

The valley-ponded ignimbrite is coarse grained with $>10 \mathrm{wt} \%>2 \mathrm{~mm}$. There is a slight tendency for grain size to decrease upward in the entire section. No significant variation was found as a function of distance from source. The over-
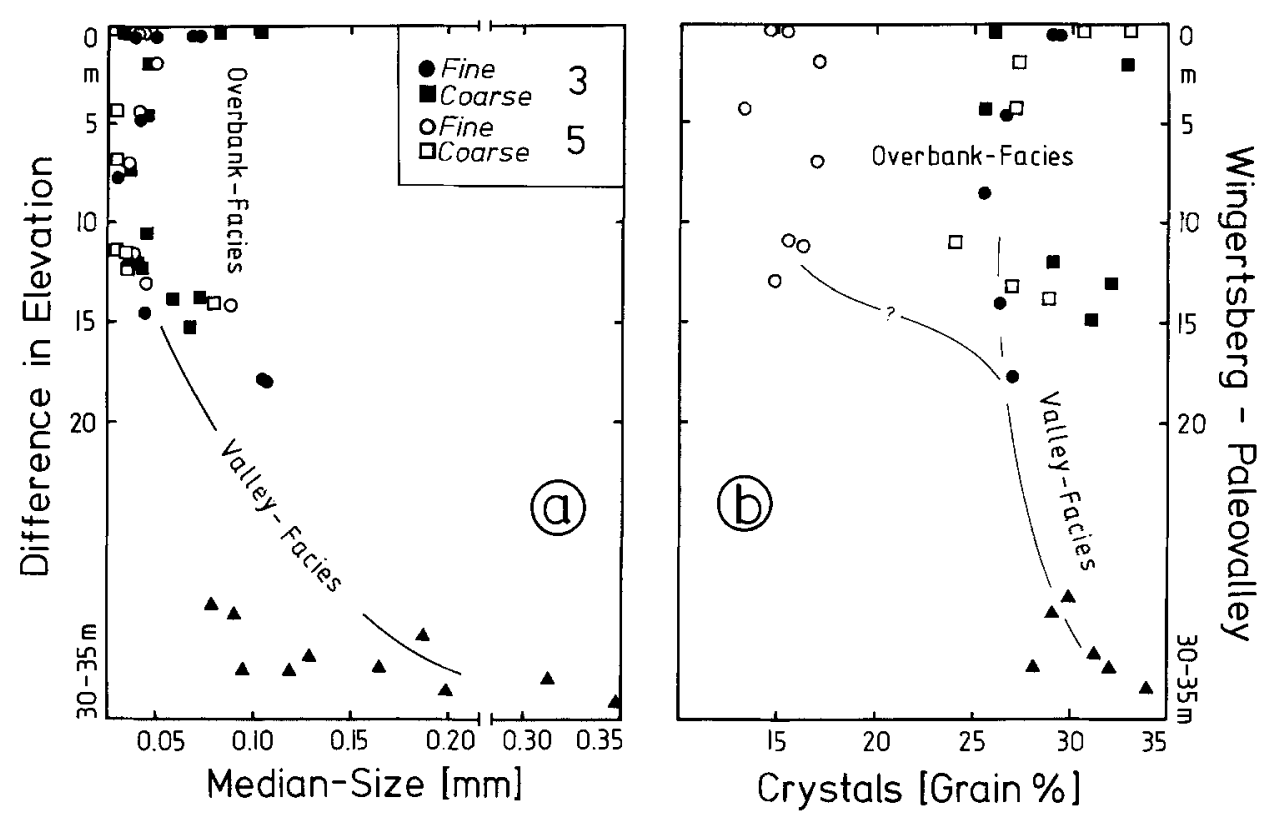

Fig. 6. Median grain size and crystal content in the 125-180- $\mu \mathrm{m}$ fraction of four individual ash layers (a fine- and a coarse-grained layer of units 3 and 5) related to the topography of paleovalley to higher ground. Vertical scale indicates meters below the average level of the overbank facies on Wingertsberg. There is a wide grain-size variation in the valley-fill decreasing with elevation. Throughout the overbank facies no variation is obvious. The fine-grained layer of unit 6 is distinctly lower in crystal content than other ash layers 


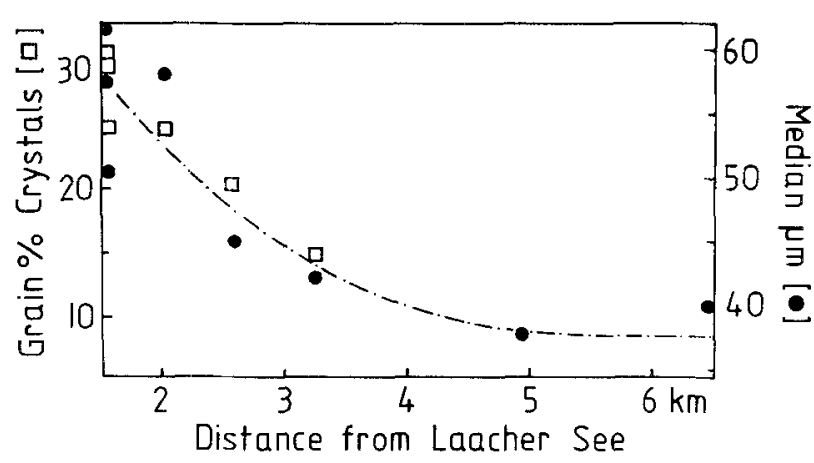

Fig. 7. Decrease in $\mathrm{Md}(\mathrm{mm})$ and crystal content in overbank deposits with increasing distance from Laacher See. Open squares represent crystal content, and dots the median

bank facies is finer grained due to lower amounts of the coarse fraction with a maximum of $3 \mathrm{wt} \%$ $>2 \mathrm{~mm}$. Two types of ash layers were distinguished within the overbank deposits: relatively coarse-grained layers with $1-3 \mathrm{wt} \%>2 \mathrm{~mm}$ and very fine grained layers no coarser than about 1 $\mathrm{mm}$. Median grain size generally decreases with increasing elevation above the paleovalley bottom, but this fining is already noticeable in the valley filling ignimbrite close to the valley margin (Fig. 6a). No topography-related, grain-size variation was found within the overbank facies. With increasing distance from source, median grain size systematically decreases in overbank deposits (Fig. 7), but remains relatively constant in the valley-fill ignimbrite.

\section{Crystal content}

Ash-sized tephra consists of glass shards, crystals, and lithics. We determined the relative abundance of free crystals in the separately sieved $1 / 2-\Phi$ fraction $0.125-0.18 \mathrm{~mm}$ to test the possibility of dense-particle fractionation during transport. We chose this fine-grained fraction because of (a) the overall fine grain size of the ash and (b) because grain counting of these particle sizes under a microscope is relatively easy. The crystal content of 15 samples was measured by counting about 1500 grains under a binocular microscope.

The amount of crystals generally varies between $33 \%$ and 16 grain $\%$ of the amount of the $0.125-0.18 \mathrm{~mm}$ fraction. Coarse-grained overbank ash layers with a maximum grain size $>2 \mathrm{~mm}$ as well as the ponded ignimbrite contain about $25 \%$ 33 grain $\%$ crystals, whereas very fine grained overbank layers with maximum grain size of about $1 \mathrm{~mm}$ contain only 16\%-18 grain $\%$ (Fig. 6b). Thus, the amount of crystals of a particular fraction correlates with the grain-size distribution of the entire sample. There is no systematic variation within individual overbank layers transverse to the direction of transport, but with increasing distance from source, crystal content systematically decreases from roughly 30 grain $\%$ north of Wingertsberg about $1.5 \mathrm{~km}$ south of Laacher See to $16 \%$ at $4.5 \mathrm{~km}$ from the vent. The decrease in crystals may be due to (a) preferential loss of heavies during transport, and (b) accumulation of fine vitric ash due to abrasion. Both processes may have operated, because even in this fine-grained fraction the general correlation of median grain size and crystal content is good (Fig. 7).

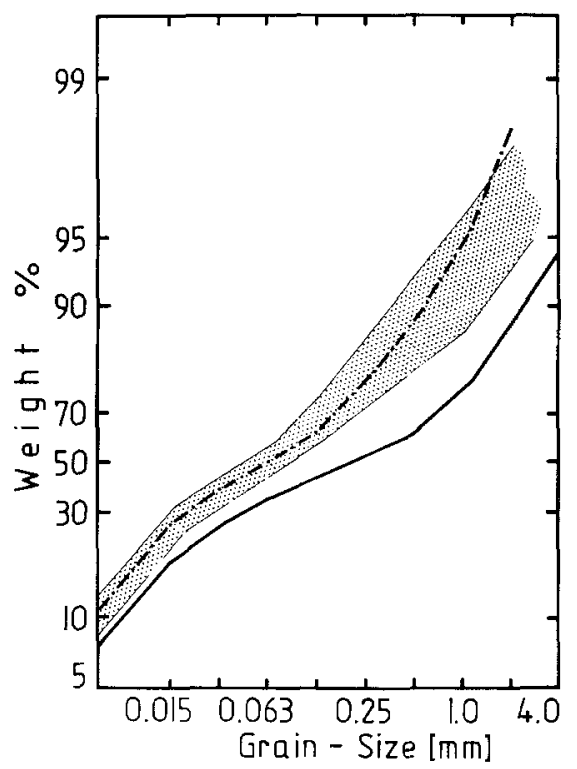

Fig. 8. Cumulative grain-size distribution illustrating facies relationships. Solid line, analyzed distribution of valley-fill sample; dotted area, variation in overbank deposits; dash-dot line, grain-size distribution of an average overbank sample calculated from the valley-fill sample by depletion of varying amounts of tephra (see Table 1)

Table 1. Depletion rates of coarse-grained tephra to generate an average overbank deposit from the valley fill

\begin{tabular}{ll}
\hline $\begin{array}{l}\text { Grain size } \\
(\mathrm{mm})\end{array}$ & $\begin{array}{l}\text { Depletion rate } \\
\text { (wt } \% \text { of fraction) }\end{array}$ \\
\hline$>4.0$ & 100 \\
$4.0-2.0$ & 80 \\
$2.0-1.0$ & 67 \\
$1.0-0.5$ & 50 \\
$0.5-0.25$ & 20 \\
\hline
\end{tabular}




\section{Depositional model of Laacher See overbank deposits}

During the last few years, several models for the mode of deposition of fine-grained ash layers during explosive eruptions have been proposed. Summarized by Walker (1981), these models include (a) pauses in eruptive activity, (b) changes in eruptive style such as influx of external water resulting in extremely fine-grained phreatomag- matic fallout beds, (c) flushing out of ash clouds by rain, (d) co-ignimbrite ash-fall deposits, and (e) deposits left after passage of pyroclastic flows (ignimbrite veneer deposit, IVD).

Our studies of field relationships and grainsize characteristics show that the model of deposition from co-ignimbrite ash clouds is inappropriate to explain the MLST-B overbank deposits. They show sedimentary features typical of flow deposits such as inverse size grading of pumice in
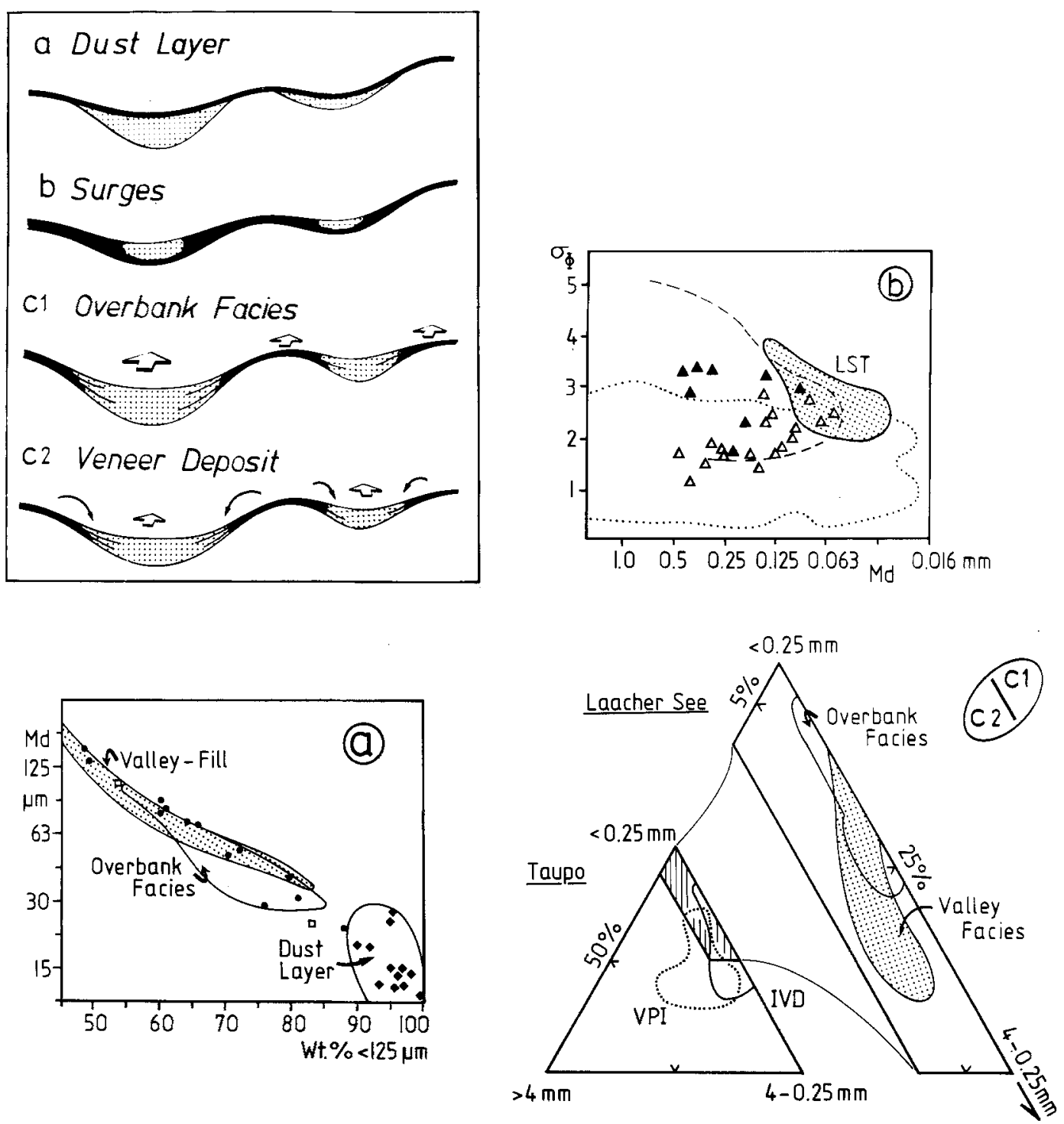

Fig. 9a, b. Diagram illustrating possible depositional models of thin ash layers on higher ground. a Dust layer deposited from co-ignimbrite ash clouds. The Md (mm) vs wt $\%<125 \mu \mathrm{m}$ diagram illustrates grain-size relationships of LS overbank, valley facies, dust layer east of Laacher See, and data of other dust layers (reference data Sparks 1976; Freundt and Schmincke 1986). b Surges. Some tephra layers show depositional characteristics of ignimbrites in thicker sections and surge characteristics on higher ground. Reference data of the

Mount St. Helens blast deposit (pyroclastic-flow unit and surge unit; data after Hoblitt et al. 1981). c1, c2 Taupo ignimbrite veneer deposit compared to the Laacher See deposits. The Taupo VPI is interpreted to originate dominantly from the draining of tephra from the interfluves into the valleys (curved arrows), whereas major portions of Laacher See pyroclastic flows are primarily concentrated in valleys. The ternary diagram indicates similar grain-size relationships between the contrasting deposits 
the upper parts of individual layers and foreset bedding behind obstacles. Furthermore, overbank ash layers are laterally continuous with the valleyfill ignimbrite instead of covering it. Grain-size characteristics also rule out the hypothesis of deposition from elutriation clouds because sorting parameters $\sigma_{\Phi}$ of overbank deposits are more typical of flow than of fall deposits (cf. Fig. 5), although some data points of co-ignimbrite ash deposits (Sparks 1976) fall into the grain-size field of Laacher See overbank samples (Fig. 9a). Grainsize analysis also show both overbank and valleyfill deposits related to each other through enrichment/depletion of large particles not likely to occur in a co-ignimbrite dust layer. A simple model calculation shows depletion of discrete amounts of lapilli- and coarse-ash-sized tephra from the valley-fill ignimbrite generating an average overbank deposit (Table 1). The cumulative distribution curve representing this theoretical (calculated) deposit matches well the variation area of the analyzed coarse-grained overbank samples (Fig. 8). The relative increase in fines $<63 \mu \mathrm{m}$ is due to the effects of constant sum.

We conclude from this relationship that the grain-size decrease in the overbank facies is due to segregation and deposition of coarse-grained tephra during flow. When a pyroclastic flow with a uniform grain-size distribution spreads away from the vent, lapilli-sized tephra is deposited earlier from thin overbank than from thicker valley flow of higher transport capacity. Thus, in a cross section at any distance from the vent, coarse tephra is fractionated into the valley flow. Ash remained suspended in the flow and is not, or only little, affected by depletion due to deposition.
Therefore, grain-size distribution of the ash matrix of valley flows is relatively constant. This model implies early segregation of coarse tephra into the lower part of the flow, which is the channelized portion, whereas the upper part - the overbank portion - is finer grained. The flow becomes vertically graded due to buoyant forces within a partially fluidized flow (Wilson 1984) while leaving the Laacher See basin and descending the outer slope. The bulk of coarse tephra segregated and deposited due to the high ground friction of the overbank flow contributing to the formation of coarse lag breccias within the Laacher See basin (Freundt and Schmincke 1985).

The bulk of flows, which may have been generated from collapsing eruption columns when the vent was plugged by breakdown of the conduit walls, left the Laacher See basin through passes between older scoria cones of the surrounding rim and was thus confined to valleys (Schmincke 1977; Bogaard and Schmincke 1984; Freundt and Schmincke 1986). The other portion, more diluted and laterally continuous with the valley flow, spread over the level ground south and east of the volcano as well as the interfluves between the major valleys (Fig. 10). While the mobility of the channelized portions can be sustained by fluidization from released gas, mobility of thin overbank flows largely depends on their ability to prevent deflation to plug flow. We attribute the wide distribution of the ash-flow blanket to the balance of deposition from various flow parts and expansion of the flow due to entrapped and heated ambient air that maintained sufficient fluidization and mobility to their distal end.
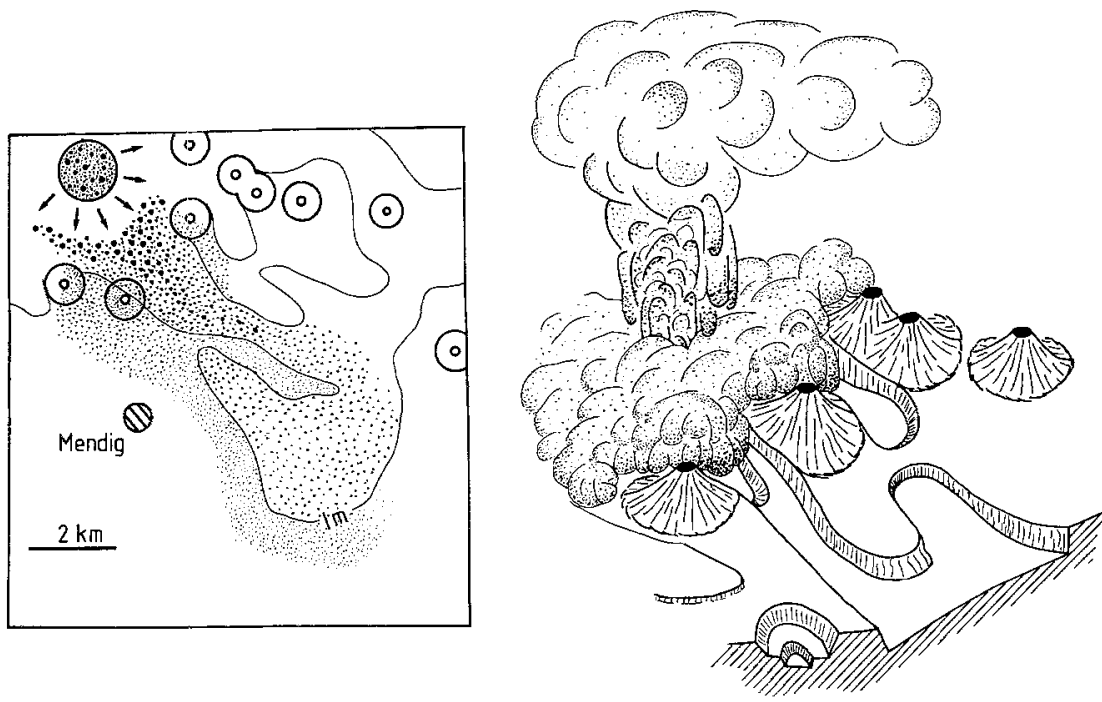

Fig. 10. Sketch illustrating emplacement of Laacher See MLST-B ignimbrites originating in eruption column collapse. A uniformly distributed material spreads out radially. The bulk of tephra is concentrated in paleovalleys due to higher transport capacity of thick flows. Coarse tephra segregated out from overbank flow portions contributing to proximal lag breccias. Remaining flow covers level ground and the interfluves. The map schematically illustrates the regional grain-size distribution pattern of the deposits (circles symbolize scoria cones) 
The thin, lithic-enriched, fines-depleted laminae separating some flow units in the proximal overbank area may be interpreted as a very fine grained type of ground layer (Walker et al. 1981a; Freundt and Schmincke 1985). These, deposited from the flow head, indicate turbulence and preferential loss of heavies sustaining sufficient mobility for the overbank flow lobes. The turbulent flow head then was maintained as a ground cloud depositing the distant, accretionary-lapilli-rich overbank facies (Schumacher 1988). Turbulence and traction transport are also indicated by local foreset bedding in the overbank deposits. Crossing irregular topography, the density and mass concentration of thin overbank flows diminished behind obstacles resulting in turbulent vortex cells. Deposits from such expanded, turbulent flow parts show cross-strata and other internal structures typical of surge deposits. The overbank deposits therefore exhibit good examples of transition from a dense flow to an inflated, turbulent ground cloud, which is here explained as caused by the interference of the flow with surface irregularities. Segregation is more obvious, of course, in the valley-fill where coarse lithic breccia layers form basal parts of flow units show imbrication of platy fragments. The pumice concentration layer on top of unit 5 was generated by buoyant rise and flotation of pumice through the flow, as is indicated by the grading of clasts. The pumice concentration layer stranded along the valley margin, pushed aside by a velocity gradient from the center of the valley to the margin (see also Freundt and Schmincke 1986). This is a mechanism roughly similar to the formation of levees observed in pyroclastic flows of the 1980 Mount St. Helens eruptions (Wilson and Head 1981). South of Laacher See volcano, levee formation was inhibited, however, because pumice laterally entered the interconnecting overbank flow lobe that rafted the concentration layer until final deposition on the flanks of Wingertsberg.

Segregation and deposition of coarse tephra from thin flow lobes as well as development of turbulent ground clouds from the flows at greater distances from the vent, which is responsible for the wide distribution of the thin tephra blanket, only appears to be possible in the case of lowdensity pyroclastic flows. Freundt and Schmincke (1986) modelled flow behaviour of Brohltal pyroclastic flows that had descended through narrow valleys north of the Laacher See (cf. Fig. 1c) as Newtonian fluids with flow densities of $600-900$ $\mathrm{kg} / \mathrm{m}^{3}$ and flow velocities of about $30 \mathrm{~m} / \mathrm{s}$. Results showed only poor coincidence with field re- lationships, so they concluded that the flows must have behaved as Bingham fluids. This may be valid for flows confined to narrow valleys, but conditions were different for unconfined flow south of the volcano. The average, loosely packed bulk density of the tephra from overbank and marginal deposits amounts to $750 \mathrm{~kg} / \mathrm{m}^{3}$. A rough estimate of flow velocities from depositional features (Wilson 1980; Wilson and Walker 1982) gives velocities of $10-30 \mathrm{~m} / \mathrm{s}$, which agrees well with Freundt and Schmincke (1986). The assumption of Newtonian flow behavior of the overbank flow portion as a first approximation appears to be valid.

\section{Discussion and comparison to similar deposits}

Our interpretation of the mode of deposition of the Laacher See pyroclastic flows is based on the assumption that coarse material is fractionated into valley-confined flows, whereas more dilute portions of the same flows were deposited on overbank areas. If segregation of coarse, dense tephra on one hand and inflation due to incorporation and heating of ambient air on the other hand play a major role in the emplacement of the flows, one should also consider the development of surges on higher ground due to low solids concentration (Fisher et al. 1980). The directed blast deposit of the 18 May 1980 Mount St. Helens eruption is a good example because there are transitions from massive valley-fill deposits to bedded deposits on higher ground. The blast deposit was subdivided into three major stratigraphic units: from bottom to top, the basal unit A0, the coarse pebble-rich layer A1, and the layer A2 enriched in ash and topped by the accretionary lapilli unit (Fisher et al. 1987). A secondary pyroclastic flow is intercalated beneath the accretionary lapilli unit filling depressions. Deposits generally thicken in topographic lows where the coarse basal part, i.e., layers $\mathrm{A} 0$ and $\mathrm{A} 1$, is thickest and the pyroclastic flow unit can be identified up to $18 \mathrm{~km}$ away from the vent. On ridge crests, deposits are significantly thinner and the ash-rich layer A2 shows internal (cross-) bedding in its upper part, which corresponds to the former surge unit defined by Hoblitt et al. (1981). Grain-size analysis shows (a) a steady grain-size decrease from bottom to top of the total deposit at a given locality, (b) a grain-size decrease from the valley-fill to deposits on ridge crests, and (c) the bedded upper part of layer A2 (surge unit) is better sorted than the massive lower part of layer A2 (massive unit) 
rather than finer grained (Hoblitt et al. 1981; Fisher et al. 1987; Fig. 9b).

Products of the initial explosion of Mount St. Helens were deposited during a single period of flow of the blast surge (Hoblitt et al. 1981; Moore and Sisson 1981; Waitt 1981; Fisher et al. 1987). The coarse layer A1 is interpreted to have been deposited from the surge head and is thus a type of ground layer deposit as defined by Walker (1981). The ash-rich layer A2 was deposited from the body of the surge. Subdivision into a massive lower and an internally bedded upper part is thought to be due to segregation processes resulting in a lower mass concentration and turbulent flow of the upper part of the blast surge. The pyroclastic flows developed due to remobilization and downslope sloughing of tephra and are thus a secondary feature (Moore and Sisson 1981; Fisher et al. 1987).

The valley-fill flow facies of the Laacher See deposits, however, is a primary feature, so a major flow portion entered the paleovalleys while leaving the Laacher See basin and advanced parallel to the overbank flow portion. Coarse lithic material is fractionated into the valley flow portion, but these breccias are interpreted as the basal part of ignimbrite flow units (basal part of layer $2 b$,
Sparks et al. 1973) rather than ground layers (Freundt and Schmincke 1986). The overbank ash layers are thin flow units, some incomplete, i.e., without the basal, lithic-rich zone showing only surface-related foreset-bedding structures, which differ from the blast-surge deposits where crossbedding is self-induced (Table 2). We assume that both the velocity of the Laacher See flows directed toward the south from the volcano was too low and the solids concentration within their lower avalanche parts too high for surge bedforms to form. This contrasts with the proximal facies of ignimbrites extending northward from the volcano, where surge deposits commonly form the proximal facies (Freundt and Schmincke 1985). Furthermore, MLST overbank deposits differ in grain-size distribution from the valley-fill, whereas those of the Mount St. Helens differ chiefly in sorting. Grain-size distribution also shows a gradual decrease from bottom to top of the blast depositional sequence which is not observed in the Laacher facies where differences occur between individual layers irrespective of their stratigraphic position - the MLST is a multiple flow deposit. In summary, overbank and valley facies of the Laacher See appear to be more similar in their internal bedding structures and grain-

Table 2. Characteristics of different, thin, bedded ash deposits related to ignimbrites and covering higher ground

\begin{tabular}{|c|c|c|c|c|}
\hline Field & Co-ignimbrite ash & Surge deposits & Veneer deposit & Overbank facies \\
\hline Area & $\begin{array}{l}\text { Extending beyond the ig- } \\
\text { nimbrite }\end{array}$ & $\begin{array}{l}\text { Tephra on elevations con- } \\
\text { tinuous with thicker tephra }\end{array}$ & \multicolumn{2}{|c|}{$\begin{array}{l}\text { Tephra on higher ground lateral continuous with valley- } \\
\text { filling ignimbrite }\end{array}$} \\
\hline Bedding & No & $\begin{array}{l}\text { Cross-strata and foreset } \\
\text { bedding }\end{array}$ & $\begin{array}{l}\text { Internal banding due to } \\
\text { fluctuation of flow }\end{array}$ & $\begin{array}{l}\text { Several ash layers, multiple } \\
\text { flow deposit }\end{array}$ \\
\hline Grading & Normally graded ash layer & No & \multicolumn{2}{|c|}{$\begin{array}{l}\text { Reversed size grading of pumice in the upper part of } \\
\text { discrete layers due to buoyant rise }\end{array}$} \\
\hline $\begin{array}{l}\text { Cross- } \\
\text { strata }\end{array}$ & No & $\begin{array}{l}\text { Self-induced, partly surface } \\
\text { related }\end{array}$ & $\begin{array}{l}\text { Mainly surface-related be- } \\
\text { hind obstacles }\end{array}$ & Surface-related \\
\hline $\begin{array}{l}\text { Transi- } \\
\text { tion to } \\
\text { ignim- } \\
\text { brite }\end{array}$ & $\begin{array}{l}\text { No transition, cover ignim- } \\
\text { brites }\end{array}$ & $\begin{array}{l}\text { Gradation from dunes to } \\
\text { massive parts }\end{array}$ & $\begin{array}{l}\text { Obscuring internal bedding } \\
\text { in valley-fill }\end{array}$ & $\begin{array}{l}\text { Obscuring of strata, ero- } \\
\text { sional disruption in the } \\
\text { valley }\end{array}$ \\
\hline $\begin{array}{l}\text { Accre- } \\
\text { tion. la- } \\
\text { pilli }\end{array}$ & $\begin{array}{l}\text { Beneath the layer, decreas- } \\
\text { ing amounts in distant ash }\end{array}$ & Abundant in upper parts & Not described & $\begin{array}{l}\text { Upper part of discrete } \\
\text { layers; increasing abun- } \\
\text { dance from source }\end{array}$ \\
\hline \multicolumn{5}{|l|}{$\begin{array}{l}\text { Grain } \\
\text { size }\end{array}$} \\
\hline Median & $\begin{array}{l} \pm 0.2 \mathrm{~mm} \\
(0.03 \mathrm{~mm} \text { in LST })\end{array}$ & $2 \mathrm{~mm}$ & $1 \mathrm{~mm}$ & $0.063 \mathrm{~mm}$ \\
\hline Sorting & $(1.5-1.9$ in LST) & $1.5-3.0$ & $2.0-3.5$ & $2.0-3.0$ \\
\hline
\end{tabular}


size relationships to the Taupo ignimbrite veneer than to the Mount St. Helens blast deposit.

\section{Taupo ignimbrite veneer deposit (IVD)}

The term ignimbrite veneer deposit was proposed for a portion of the Taupo ignimbrite, New Zealand (Walker et al. 1980, 1981b; Wilson and Walker 1982, 1985; Wilson 1985). The thin deposit, only $0.5-1 \mathrm{~m}$ thick over most of its extent, covers interfluves between valleys filled by a much thicker ignimbrite. Mantling topography, ash layers are deposited on slopes as steep as $30^{\circ}$. The IVD shows internal bedding due to grading of pumice and lithics out to about $40 \mathrm{~km}$ from the vent. Leeside lenses behind obstacles showing internal cross-strata consist of well-rounded pumice. The IVD is laterally continuous with the valleyponded ignimbrite (VPI), though bedding due to pumice concentration becomes less distinct in the valley fill.

Based on the the grain-size characteristics, deposits form two overlapping fields in a ternary grain-size variation diagram (Fig. 9c). The Taupo veneer deposit and the ponded ignimbrite show similar grain-size distribution patterns except for the smaller maximum pumice size in the veneer (Wilson and Walker 1982, 1985). With increasing distance from source, mean grain size decreases so that in distant areas differences between the contrasting facies are less obvious. Despite the overall finer grain size of the Laacher See deposits, overbank and valley facies show similar grain size differences (Fig. 9c-d).

The Taupo tephra deposits thus resemble the Laacher See flow deposits in many respects, especially field relationships: both show internal bedding due to pumice concentrations, and they drape irregular surfaces and laterally merge into a valley-fill ignimbrite. Grain size of deposits on higher ground compared to that in valleys are also similar irrespective of the overall finer grain size of the analyzed Laacher See deposits.

The Taupo IVD is interpreted to have been deposited from the basal and trailing parts of a high-velocity pyroclastic flow left behind because of ground friction. While the basal parts slowed down, the upper, more mobile parts drained into the valleys forming the VPI (Wilson and Walker 1985). Thus, the IVD is the uphill facies of the Taupo ignimbrite and the valley-fill, at least part$1 y$, resulted from secondary slumping or remobilization of tephra from the slopes. The latter is the principal difference to the Laacher See deposits.

\section{Conclusions}

Detailed studies of field relationships and grainsize characteristic of 0.5 - to 1.5 -m-thick, beddedash deposits south of Laacher See volcano show them to be laterally continuous with valley-fill ignimbrites totalling approximately $6-10 \mathrm{~m}$ in thickness. We use the term overbank facies for the thin, bedded deposits on higher ground and valley facies for the ponded ignimbrite. Internal structures of discrete layers of the overbank facies include inversely graded pumice in the upper parts and foreset-bedding structures behind obstacles and other surface irregularities. Bedding is laterally transitional to the much thicker valley-fill. Grainsize characeristics show the overbank deposits to be finer grained than the valley-fill. Two overlapping data sets in a ternary diagram indicate close relationship of both grain populations; simple model calculation shows that depletion of discrete amounts of lapilli- to coarse-ash-sized tephra generates an average overbank deposit from the valley-fill.

The Laacher See overbank deposits show many similarities to the Taupo ignimbrite veneer deposit (IVD). The IVD is interpreted by Wilson and Walker (1982) to have been left behind after passage of a highly mobile pyroclastic flow. Part of the deposit on higher ground drained into valleys forming a much thicker ponded ignimbrite VPI. Thus, the IVD is a pyroclastic-flow depositional facies. There is generally good correlation in facies relationships of valley to overbank in the Taupo and in the Laacher See area. Internal bedding structures of thin tephra layers are laterally transitional to the valley-fill. Differences such as cross-strata not related to topography can be attributed to the much higher flow velocity of the Taupo pyroclastic flow. Grain-size distribution patterns from valley to overbank are also closely similar except for the apparently finer grain size of the Laacher See deposits. Principal differences are that the Laacher See deposit is a multiple flow deposit, whereas the Taupo ignimbrite is derived from a single flow and the Taupo VPI is drained into the depressions from the deposits on higher ground, whereas the Laacher See valley-fill was deposited primarily from confined flow portions.

These differences can be attributed to eruption parameters such as mass eruption rate, eruption column height, and local topography. The contrasting deposits in both areas are here regarded as a depositional facies of pyroclastic flows rather than as a distinct types of pyroclastic rocks as proposed by Walker et al. (1980, 1981b). We 
introduce the term overbank facies for the Laacher See deposits on higher ground, because the major flow portion is confined to the paleovalley parallel to the flow direction and a volumetrically small, but widespread portion covers the banks outside the valley.

Acknowledgements. This study is part of the MA thesis by RS. Our work was supported by grants from the Ministerium für Wissenschaft und Forschung. We thank Colin Wilson, Richard Fisher, Haraldur Sigurdsson, Armin Freundt, and Paul van den Bogaard for critical and helpful comments on various versions of the manuscript. We also appreciate Almut Fischer's patience printing the photographs.

\section{References}

Bogaard Pvd, Schmincke H-U (1984) The eruptive center of the late Quaternary Laacher See Tephra. Geol Rundsch 73:935-982

Bogaard Pvd, Schmincke H-U (1985) Laacher See Tephra: a widespread isochronous late Quaternary tephra layer in central and northern Europe. Geol Soc Am Bull 96:15541571

Fisher RV, Smith AL, Wright JV, Roobol MJ (1980) Ignimbrite veneer deposits or pyroclastic surges? Nature 286:912

Fisher RV, Glicken HX, Hoblitt RP (1987) May 18, 1980, Mount St Helens deposits in south Coldwater Creek, Washington. J Geophys Res 92:10267-10283

Frechen J (1953) Der theinische Bimsstein. Fischer, Wittlich, pp $1-75$

Frechen J (1976) Siebengebirge am Rhein, Laacher Vulkangebiet, Maargebiete der Westeifel. Sammlung Geol Führer 56, 3rd edn. Borntraeger, Berlin, pp 1-209

Freundt A, Schmincke H-U (1985) Lithic-enriched segregation bodies in pyroclastic flow deposits of Laacher See volcano (E-Eifel, Germany). J Volcanol Geotherm Res 25:193-224

Freundt A, Schmincke H-U (1986) Emplacement of small-volume pyroclastic flows at Laacher See (East-Eifel, Germany). Bull Volcanol 48:39-59

Hoblitt RP, Miller CD, Vallance JW (1981) Origin and stratigraphy of the deposits produced by the May 18 directed blast. In: PW Lipman, DR Mullineaux (eds) The 1980 eruptions of Mount St Helens, Washington. USGS Prof Paper 1250:401-419

Moore JG, Sisson TW (1981) Deposits and effects of the May 18 pyroclastic surge. In: PW Lipman, DR Mullineaux (eds) The 1980 eruptions of Mount St Helens, Washington. USGS Prof Pap 1250:421-438

Schmincke H-U (1970) Base-surge Ablagerungen des Laacher See Vulkans. Aufschluß 21:359-364

Schmincke H-U (1977) Eifel-Vulkanismus östlich des Gebietes Rieden-Mayen. Fortschr Mineral Beih 55:1-31

Schmincke H-U, Bogaard Pvd, Freundt A, Park C, Schumacher R (1989) Evolution of complex Plinian eruptions: the Late Quaternary Laacher See case history - a progress report. Extended abstract 3rd Internat Thera Conference, Sartorini
Schumacher R (1988) Aschenaggregate in vulkaniklastischen Transportsystemen. PhD-thesis Universität Bochum, pp 1139

Schumacher R, Schmincke H-U (1987) Aggregatsedimentation aus windverdrifteten Aschewolken östlich des Laacher See Vulkans. Heidelberger Geowiss Abh 8:215-216 (abstr)

Sparks RSJ (1976) Grain-size variations in ignimbrites and implications for the transport of pyroclastic flows. Sedimentology $23: 147-188$

Sparks RSJ, Self S, Walker GPL (1973) Products of ignimbrite eruptions. Geology 1:115-118

Waitt RB (1981) Devastating pyroclastic density flow and attendant air fall of May 18 - stratigraphy and sedimentology of deposits. In: PW Lipman, DR Mullineaux (eds) The 1980 eruptions of Mount St Helens, Washington. USGS Prof Pap 1250:439-458

Walker GPL (1971) Grain-size characteristics of pyroclastic deposits. J Geol 79:696-714

Walker GPL (1981) Plinian eruptions and their products. Bull Volcanol 444:223-240

Walker GPL, Croasdale R (1971) Two Plinian-type eruptions in the Azores. I Geol Soc London 127:17-55

Walker GPL, Heming RF, Wilson CJN (1980) Low -- aspect ratio ignimbrites. Nature 283:286-287

Walker GPL, Self S, Froggatt PC (1981a) The ground layer of the Taupo ignimbrite: a striking example of sedimentation from a pyroclastic flow. J Volcanol Geotherm Res 10:111

Walker GPL, Wilson CJN, Froggatt PC (1981b) An ignimbrite veneer deposit: the trail marker of a pyroclastic flow. J Volcanol Geotherm Res 9:409-421

Wilson CJN (1980) The role of fluidization in the emplacement of pyroclastic flows: an experimental approach. J Volcanol Geotherm Res 8:231-249

Wilson CJN (1984) The role of fluidization in the emplacement of pyroclastic flows, 2: Experimental results and their interpretation. $\mathrm{J}$ Volcanol Geotherm Res 20:55-84

Wilson CIN (1985) The Taupo eruption, New Zealand II. The Taupo ignimbrite. Phil Trans R Soc London A 314:229310

Wilson CJN, Walker GPL (1982) Ignimbrite depositional facies: the anatomy of a pyroclastic flow. $J$ Geol Soc London 139:581-592

Wilson CJN, Walker GPL (1985) The Taupo eruption, New Zealand I. General aspects. Phil Trans R Soc London A 314:199-228

Wilson L, Head JW (1981) Morphology and rheology of pyroclastic flows and their deposits, and guidelines for future observations. In: PW Lipman and DR Mullineaux (eds) The 1980 eruptions of Mount St Helens, Washington. US Geol Surv Prof Pap 1250:513-524

Received July 28, 1987/Accepted June 20, 1989 